\title{
Generalized Procrustes Analysis and External Preference Map Used to Consumer Drivers of Diet Gluten Free Product
}

\author{
A. A. Mauricio, A. B. Palazzo", V. M. Caselato, H. M. A. Bolini \\ Department of Food and Nutrition, School of Food Engineering, University of Campinas (UNICAMP), Campinas, \\ Brazil \\ Email: *alessandrabpalazzo@gmail.com
}

Received 26 April 2016; accepted 22 July 2016; published 25 July 2016

Copyright (C) 2016 by authors and Scientific Research Publishing Inc.

This work is licensed under the Creative Commons Attribution International License (CC BY). http://creativecommons.org/licenses/by/4.0/

(c) (i) Open Access

\section{Abstract}

In order to study correlations between sensory properties and acceptance, regular and gluten-free carrot cakes (sweetened with sucrose and sucralose) were evaluated. Appearance, aroma, flavor, texture and overall liking were analyzed by 120 carrot cake consumers using a 9-cm hedonic scale. Quantitative Descriptive Analysis (QDA) was carried out with 11 assessors among 16 attributes. Data were analyzed by ANOVA, Tukey test ( $p<0.05)$, Internal Preference Map and Cluster analysis. Also texture parameters were analyzed by Partial Least Square (PLS) to be able to show the instrumental parameters influence. Generalized Procrustes Analysis (GPA) was used before an External Preference Mapping to reduce the scale effects and to obtain a consensus configuration. According to PLS correlation, the attributes hardness, fracturability, adhesiveness, chewiness and gumminess interfered on characteristics considered undesirable for texture acceptance and smoothness, elasticity, cohesiveness and water activity interfered as desirable features. It was noted that all cakes were well accepted, except cake sweetened with sucralose and mix done using cornmeal, rice flour, potato starch and corn starch (2:3:3:2). As for the instrumental aspects, cohesiveness and elasticity influenced positively the cake's acceptance. Instead, smoothness and adhesion parameters weren't so significant.

\section{Keywords}

Gluten-Free, Correlation, Partial Least Square, Procrustes

\footnotetext{
${ }^{*}$ Corresponding author.
}

How to cite this paper: Mauricio, A.A., Palazzo, A.B., Caselato, V.M. and Bolini, H.M.A. (2016) Generalized Procrustes Analysis and External Preference Map Used to Consumer Drivers of Diet Gluten Free Product. Food and Nutrition Sciences, 7, 711-723. http://dx.doi.org/10.4236/fns.2016.79072 


\section{Introduction}

The Celiac Disease (CD) is characterized by a permanent gluten intolerance, consisting in the gluten protein exclusion from diet during entire life. Thus it's important to keep on diet without gluten in order to preserve the intestinal microvilli, increasing macro and micro-nutrients absorption and improving the digestive system [1]-[3].

Celiac patients state that sensory appropriate foods offered are limited and still note that gluten-free feed available is more expensive [4].

Wheat is the second grain most consumed in world [5], and also applied on processing, transforming and preparing of industrialized foods [6].

It's hard to find gluten replacement in some products; however it's possible to preserve most of the sensorial attributes, providing other possibilities of food for people living with celiac disease [7]. Among the baked goods, cake is a historical and globally consumed food. The Brazilian consumption of cake rate is 14 g/day per person [8].

The analysis of acceptance may reflect the degree of acceptance of a particular product by general consumers [9].

The GPA usually provides a consensus picture of the data from each individual panellist in two or three dimensional space to obtain a consensus result [10].

Descriptive analysis still stands as the most comprehensive, flexible and useful sensory method, providing detailed information on all of products' sensory properties [11].

For external preference mapping, the sensory perceptual space is set by sensory descriptive or instrumental data. Consumer preference was after used to supplement the analysis [12] [13].

In face of the context stated, this research ending point is to analyze instrumental, sensory profile and acceptance in diet and sucrose carrot cake samples, in order to give another food choice for people living with celiac disease.

\section{Material and Methods}

Seven different carrot cakes were prepared-a traditional one (prepared with wheat flour and sweetened only with sucrose) and others gluten free samples, which differ regarding their sweetener sucralose (SPLENDA Micronized Powder, Johnson and Johnson) and mix of gluten-free flours (Agroindustrial Potato Starch Lina ${ }^{\circledR}$, Rice Flour Naturato $^{\circledR}$, ADRAM Corn Starch ${ }^{\circledR}$ and YOKI Cassava Flour ${ }^{\circledR}$ ). As shown in Table 1, the sucrose of diet cakes was replaced by polydextrose (Litesse ${ }^{\circledR}$, Danisco) and maltitol (Cargill, Minneapolis, MN) as bulking agents. The different proportions used in mix flours are described in Table 2.

Table 1. Recipes used in traditional, gluten-free and diet carrot cakes.

\begin{tabular}{cccccccc}
\hline Ingredients (\%) & PDR & SG-1 & SGD-1 & SG+1 & SGD+1 & SGSF & SGFD \\
\hline Wheat flour & 20.58 & - & - & - & - & - & - \\
Mix-1 & - & 19.09 & 19.09 & - & - & - & - \\
Mix+1 & - & - & - & 19.09 & 19.09 & - & - \\
Mix w/o corn flour & - & - & - & - & - & 19.09 & 19.09 \\
Eggs & 17.64 & 21.81 & 21.81 & 21.81 & 21.81 & 21.81 & 21.81 \\
Baking soda & 1.47 & 1.72 & 1.81 & 1.72 & 1.81 & 1.72 & 1.81 \\
Refined sucrose & 26.47 & 24.54 & - & 24.54 & - & 24.54 & - \\
Polydextrose & - & - & 14.54 & - & 14.54 & - & 14.54 \\
Maltitol & - & - & 9.81 & - & 9.81 & - & 9.81 \\
Sucralose & - & - & 0.03 & - & 0.03 & - & 0.03 \\
Cooked carrots & - & 22.72 & 22.72 & 22.72 & 22.72 & 22.72 & 22.72 \\
Raw carrots & 24.51 & - & - & - & - & 10 & - \\
Corn oil & 9.8 & 10 & 10 & 10 & 10 & 10 \\
\hline
\end{tabular}

PDR: Standard; SG-1: gluten free (mix-1); SGD-1: gluten free (mix-1); SG+1: Gluten free (mix+1); SGD+1: Gluten free (mix+1); SGSF: Gluten free (mix w/o corn flour); SGFD: Gluten free (mix w/o corn flour). 
Table 2. Recipes used in mix flours of carrot cakes.

\begin{tabular}{cccc}
\hline Ingredients & MIX-1 & MIX+1 & MIX W/O CORN FLOUR \\
\hline Corn flour (g) & 300 & 600 & ----- \\
Rice flour (g) & 1200 & 900 & 600 \\
Potato starch (g) & 1200 & 900 & 600 \\
Corn starch (g) & 300 & 600 & 60 \\
\hline
\end{tabular}

\subsection{Sample Preparation}

All carrot cakes were produced firstly mixing all dry ingredients twice, except baking powder. Then, carrot, oil and eggs were mixed in the blender Kitchen-Aid model K5SS (Kitchen-Aid, St. Joseph, MI). The dry ingredients were added to the mixture, using a mixer, until a homogeneous mass was formed. Finally, the baking powder was added and gingerly mixed. The final mass was divided into three disposable aluminum cake $350 \mathrm{~g}$ capacity dispenser.

The cakes were baked $\left(180^{\circ} \mathrm{C}-200^{\circ} \mathrm{C} / 26\right.$ - $\left.30 \mathrm{~min}\right)$ in electrical oven (Brastemp).

\subsection{Sensory Analysis}

The sensorial analysis study was previously approved by the Ethic \& Research Committee (n628/CEP-HUJM/ 09).

Twenty-gram samples of carrot cake were presented in disposable plastic plates coded with a three-digit number. All samples were evaluated at room temperature. Sensory analyses were carried out in individual airconditioned $\left(22^{\circ} \mathrm{C}\right)$ booths with white light in the Sensory Analysis Laboratory of the School of Food Engineering/UNICAMP/Brazil.

\subsection{Affective Test}

One hundred and twenty volunteers were asked to take part and all rules were exposed to them. The judges were potential consumers of carrot cake and no experience was needed. They were recruited among UNICAMP undergraduates, graduates and employees, who showed interest in becoming subjects of the sensory test.

Appearance, aroma, flavor, texture and overall liking of the carrot cake samples were analyzed using a ninecentimeter unnustructured scale, anchored by their extreme ends labeled " extreme disgust" (left) and "extreme delicious" (right). For this test, fifteen-gram sample $(2 \mathrm{~cm} \times 2 \mathrm{~cm} \times 2 \mathrm{~cm})$ were presented. A complete balanced block was used [14] and the samples were presented sequentially in a monadic way.

\subsection{Quantitative Descriptive Analysis}

Judges with previous experience in descriptive analyses were preselected among Department students and Staff. Judges discussed all generated attributes and ordered a final list with 16 attributes, definitions and references using Kelly's Repertory Grid Methodology [15] (Table 3). Then panelists were further trained about attributes using the references within six 50 min sessions. Twelve panelists were selected according to their discriminating capability ( $p>0.30$ ) and repeatability ( $<0.05)$; consensus between judges was also considered [16]. A GPA was used to remove scaling effects (some experts might use a wider scale) or position effects (some experts might tend to use more the lower or the higher part of the rating scales), to obtain a consensus configuration that will be used in an external preference mapping.

The 12 selected panelists were further trained for four more repetitions, using a 9-cm unstructured line scale anchored with "none" or "weak". Seven samples in each session were monadically presented using a balanced block design [14].

Crackers and taste-free water were provided for palate cleansing.

\subsection{Instrumental Analysis}

The texture evaluation used TAXT2 texture analyzer equipped with an aluminum cylindrical probe. Conditions used in texture test are shown in Table 4 and the instrumental parameters evaluated in three repetitions were 
hardness, smoothness, adhesiveness, gumminess, chewiness, cohesiveness, fracturability and elasticity.

The water activity (Wa) was measured three times using AquaLab ${ }^{\circledR}$ equipment.

Table 3. Texture parameters in instrumental test of carrot cakes.

\begin{tabular}{cc}
\hline Texture analysis & Parameters \\
Test speed & $2 \mathrm{~mm} / \mathrm{s}$ \\
Pre test speed & $5 \mathrm{~mm} / \mathrm{s}$ \\
Post test speed & $5 \mathrm{~mm} / \mathrm{s}$ \\
Strength in contact & $50 \mathrm{~g}$ \\
Distance & $15 \mathrm{~mm}$ \\
\hline
\end{tabular}

Table 4. Descriptors used for sensory profiling of carrot cake.

\begin{tabular}{|c|c|c|c|}
\hline Descriptor & Abbreviation & Definition & References \\
\hline \multicolumn{4}{|c|}{ Appearence } \\
\hline Crumb yellow color & Color1 & Refer to yellow color (under white light) & $\begin{array}{l}\text { Weak: Ruffles }{ }^{\circledR} \text { potato } \\
\text { Strong: brown sweet Fugini }{ }^{\circledR}\end{array}$ \\
\hline Crust yellow color & Color2 & Refer to caramel color (under White light) & $\begin{array}{l}\text { Weak: brown sweet Fugini }{ }^{\circledR} \\
\text { Strong: apricot jam Queensberry }\end{array}$ \\
\hline Dry appearence & App1 & Refer to dry appearence after baked cake & $\begin{array}{l}\text { Weak: wheat cake with milk (80 ml) } \\
\text { Strong: corn cake Casa Suíça }{ }^{\circledR}\end{array}$ \\
\hline Porosity & App2 & Refer to size bubbles formed after baked cake & $\begin{array}{l}\text { Weak: Bush Scott brite }{ }^{\circledR} \\
\text { Strong: bath bush }\end{array}$ \\
\hline \multicolumn{4}{|c|}{ Aroma } \\
\hline Sweet aroma & Aro1 & Refer to sucrose & $\begin{array}{l}\text { Weak: milk Itambé }{ }^{\circledR} \\
\text { Strong: condensed milk Elegê } \hat{e}^{\circledR}\end{array}$ \\
\hline Carrot aroma & Aro2 & Refer to carrot aroma after baked cake & $\begin{array}{l}\text { Weak: } 30 \text { g carrot with } 120 \mathrm{ml} \text { water } \\
\text { Strong: } 100 \text { g carrot with } 80 \mathrm{ml} \text { water }\end{array}$ \\
\hline Corn flour aroma & Aro3 & Refer to corn aroma after baked cake & $\begin{array}{l}\text { Weak: água } \\
\text { Strong: } 250 \mathrm{~g} \text { Angu Milharina }{ }^{\circledR} \text { with } 800 \mathrm{ml} \text { water } \\
\text { heated for } 6 \text { minutes }\end{array}$ \\
\hline \multicolumn{4}{|c|}{ Flavor } \\
\hline Sweetness & Fla1 & Refer to sucrose in aqueous solution & $\begin{array}{l}\text { Weak: Sucrose solution 5\% União }{ }^{\circledR} \\
\text { Strong: Sucrose solution 15\% União }{ }^{\circledR}\end{array}$ \\
\hline Corn flour flavor & Fla2 & Refer to cornmeal flavor after baked cake & $\begin{array}{l}\text { Weak: water } \\
\text { Strong: } 250 \text { g Angu Milharina }{ }^{\circledR} \text { with } 800 \mathrm{ml} \text { water } \\
\text { heated for } 6 \text { minutes }\end{array}$ \\
\hline Carrot flavor & Fla3 & Refer to carrot flavor after baked cake & $\begin{array}{l}\text { Weak: carrot juice suco de cenoura } \\
\text { Strong: concentrated carrot juice (120 g carrot } \\
\text { with } 1 \mathrm{~L} \text { water) }\end{array}$ \\
\hline \multicolumn{4}{|c|}{ Texture } \\
\hline Moisture & Tex1 & Water sensation in baked cake & $\begin{array}{l}\text { Weak: bread Panco }{ }^{\circledR} \\
\text { Strong: brown sweet Fuggini }{ }^{\circledR}\end{array}$ \\
\hline Fracturability & Tex2 & Refer to get a cake slice with the fingers & $\begin{array}{l}\text { Weak: bread Premium Panco }{ }^{\circledR} \\
\text { Strong: Champagne cookie Bauducco }{ }^{\circledR}\end{array}$ \\
\hline Sandiness & Tex3 & Amount of realizable particles while chewing & $\begin{array}{l}\text { Weak: water } \\
\text { Strong: corn cake Casa Suíça }{ }^{\circledR}\end{array}$ \\
\hline Adhesiviness & Tex4 & $\begin{array}{l}\text { Strength to overcome the tension between } \\
\text { food and the palate }\end{array}$ & $\begin{array}{l}\text { Weak: Champagne cookie Bauducco }{ }^{\circledR} \\
\text { Strong: gnocchi Mezzani }{ }^{\circledR}\end{array}$ \\
\hline Smoothness & Tex5 & $\begin{array}{l}\text { Minimum force needed to compress the } \\
\text { sample between the teeth }\end{array}$ & $\begin{array}{l}\text { Weak: bread Panco }{ }^{\circledR} \\
\text { Strong: bread with egg sponge Panco }{ }^{\circledR}\end{array}$ \\
\hline Elasticity & Tex6 & $\begin{array}{l}\text { Cake's characteristic to return to its original } \\
\text { position after compression }\end{array}$ & $\begin{array}{l}\text { Weak: bread Panco }{ }^{\circledR} \\
\text { Strong: bath bush Esponjex }{ }^{\circledR}\end{array}$ \\
\hline
\end{tabular}




\subsection{Statistical Analysis}

The results of the acceptance tests were evaluated by unvaried statistical analysis (ANOVA), Tukey test averages ( $\mathrm{p} \geq 0.05)$ and Internal Preference Map multivariate statistical analysis [17].

Recorded data was analyzed by generalized Procrustes analysis (GPA), using XLStat [18]. GPA was used to provide information on the inter-relationships between samples and assessors [10] [19] [20].

Correlation among sensory and instrumental results was analyzed by Partial Least Square (PLS) [21] and a cluster analysis using XLStat [18].

\section{Results and Discussion}

\subsection{Consumer Test}

The consumers profile were carried out and the following information was obtained: $72.5 \%$ were female, $76 \%$ between 18 and 25 years, 15\% between 26 and 30 years and only 9\% above 30 years old.

According to the means of acceptance test of carrot cake samples (Table 5), the only sample statistically different was SGD+1, with low acceptance $(\mathrm{p}<0.05)$ at regards of attributes of appearance, aroma and overall liking.

These results could be explained by sucralose associated with a high concentration of corn flour, decreasing the consumer acceptance. Even as BATTOCHIO et al. (2006) noticed when comparing linseed cakes with sucrose substitutes, some positive cake attributes were disguised using sucralose.

Regarding flavor, the sample with highest mean was SGSF, which didn't significantly differ from its diet version (SGFD), traditional sample (PDR) and samples SG+1 and SGD-1. The same results can be found in texture attribute, in which samples PDR, SG-1, SGD-1, SGSF and SGFD were statistically similar. Thus, the alternatives for gluten-free, diet or not, carrot cake should be developed without corn flour or in less quantity.

\subsection{Quantitative Descriptive Analysis}

As shown in Table 6, the corn flour brought high changes to traditional cakes: strong yellow color, dry aspect, corn aroma and flavor. Sae-Eaw et al. [22] had a successful results by the American consumers that participated in their test, developing a product with rice flour, aimed a gluten free cake.

As reported by Battochio et al. [23], curiously the judges didn't list any negative attribute about artificial sweetener in QDA test, such as bitterness, sweet aftertaste or residual bitterness.

The dry appearance attribute was significantly noted in samples using high cornmeal concentration $(\mathrm{mix}+1)$. For fracturability and sandness the samples using cornmeal statistically differ from the others $(\mathrm{p}<0.05)$.

At the same time, cakes with corn flour were less elastic, as it also noted by Rocha et al. [24] on different proportions of gluten-free cakes.

According to the residuals by object from GPA (Figure 1), the SGD-1 and SG+1 have the smallest residual, implying that was probably a consensus between experts about the samples.

Table 5. Means of acceptance test of carrot cakes $(n=120)$.

\begin{tabular}{|c|c|c|c|c|c|}
\hline Samples & Appearance & Aroma & Flavor & Texture & Overall liking \\
\hline PDR & $7.31^{\mathrm{a}}$ & $6.92^{\mathrm{a}}$ & $7.32^{\mathrm{ab}}$ & $7.86^{\mathrm{a}}$ & $7.3^{\mathrm{a}}$ \\
\hline SG-1 & $7.33^{\mathrm{a}}$ & $6.71^{\mathrm{a}}$ & $7.09^{\mathrm{ab}}$ & $6.82^{\mathrm{ab}}$ & $6.79^{\mathrm{a}}$ \\
\hline SGD-1 & $7.14^{\mathrm{a}}$ & $7.01^{\mathrm{a}}$ & $7.11^{\mathrm{ab}}$ & $6.82^{\mathrm{ab}}$ & $7.08^{\mathrm{a}}$ \\
\hline $\mathrm{SG}+1$ & $7.12^{\mathrm{a}}$ & $6.70^{\mathrm{a}}$ & $6.76^{\mathrm{b}}$ & $6.71^{\mathrm{ab}}$ & $6.85^{\mathrm{a}}$ \\
\hline $\mathrm{SGD}+1$ & $5.37^{\mathrm{b}}$ & $5.45^{\mathrm{b}}$ & $5.21^{\mathrm{c}}$ & $5.72^{\mathrm{b}}$ & $5.35^{\mathrm{b}}$ \\
\hline SGSF & $7.31^{\mathrm{a}}$ & $6.82^{\mathrm{a}}$ & $7.38^{\mathrm{a}}$ & $7.05^{\mathrm{a}}$ & $7.16^{\mathrm{a}}$ \\
\hline SGFD & $6.92^{\mathrm{a}}$ & $6.75^{\mathrm{a}}$ & $7.02^{\mathrm{ab}}$ & $6.87^{\mathrm{ab}}$ & $6.92^{\mathrm{a}}$ \\
\hline $\mathrm{R}^{2}$ & 0.145861 & 0.082596 & 0.184276 & 0.035874 & 0.133044 \\
\hline $\operatorname{Pr}>F$ & $<0.0001$ & $<0.0001$ & $<0.0001$ & $<0.0001$ & $<0.0001$ \\
\hline
\end{tabular}

*Means with a same superscript letter are not significantly different ( $>$ > 0.05). PDR: Standard; SG-1: gluten free (mix-1); SGD-1: gluten free (mix-1); SG+1: Gluten free (mix+1); SGD+1: Gluten free (mix+1); SGSF: Gluten free (mix w/o corn flour); SGFD: Gluten free (mix w/o corn flour). 


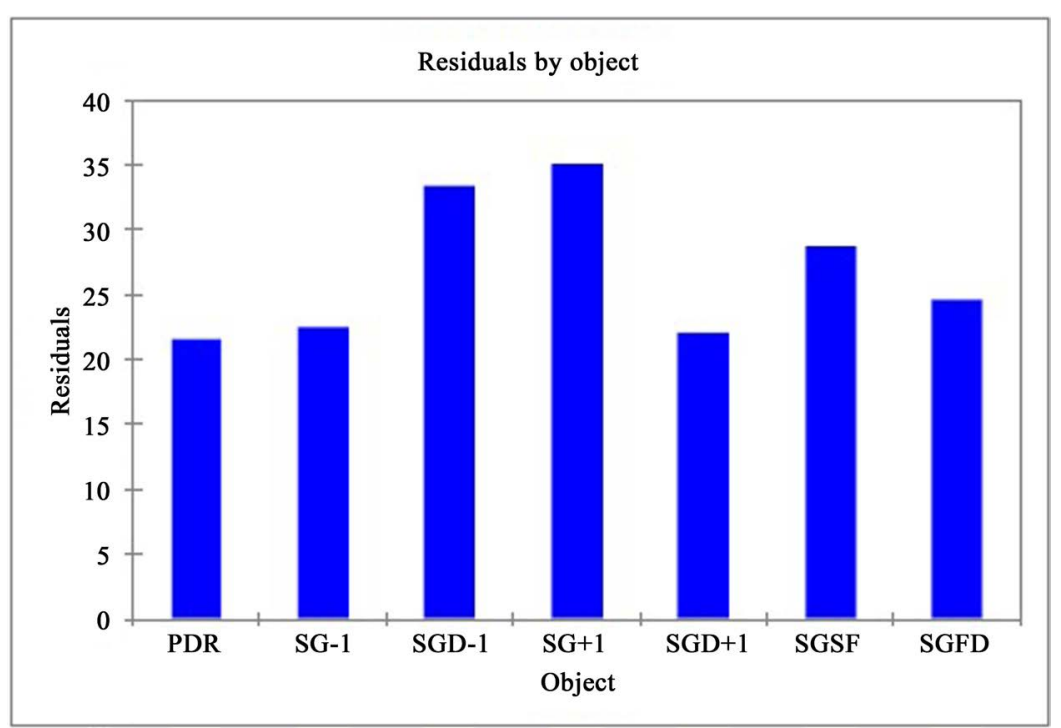

Figure 1. Residuals by object (GPA analysis).

Table 6. Attribute means* for each sample $(\mathrm{n}=11)$.

\begin{tabular}{|c|c|c|c|c|c|c|c|c|c|}
\hline \multirow{2}{*}{ Parameters } & \multicolumn{7}{|c|}{ Samples } & \multirow{2}{*}{$\mathrm{R}^{2}$} & \multirow{2}{*}{$\operatorname{Pr}>F$} \\
\hline & PDR & $\mathrm{SG}+1$ & SG-1 & $\mathrm{SGD}+1$ & SGD-1 & SGFD & SGSF & & \\
\hline Color1 & $5.97^{\mathrm{bc}}$ & $5.99^{\mathrm{bc}}$ & $5.82^{c}$ & $6.18^{\mathrm{b}}$ & $7.02^{\mathrm{a}}$ & $5.23^{\mathrm{d}}$ & $5.6^{\text {cd }}$ & $<0.0001$ & 0.3338 \\
\hline Color2 & $4.32^{\mathrm{bc}}$ & $4.54^{\mathrm{bc}}$ & $4.92^{\mathrm{b}}$ & $6.25^{\mathrm{a}}$ & $6.03^{\mathrm{a}}$ & $4.17^{\mathrm{c}}$ & $3.99^{c}$ & $<0.0001$ & 0.4528 \\
\hline App1 & $5.77^{\mathrm{b}}$ & $6.74^{\mathrm{a}}$ & $4.08^{c}$ & $6.29^{\mathrm{ab}}$ & $2.69^{d}$ & $4.13^{c}$ & $5.88^{\mathrm{b}}$ & $<0.0001$ & 0.6357 \\
\hline App2 & $6.03^{\mathrm{a}}$ & $5.23^{b}$ & $4.91^{\mathrm{b}}$ & $5.12^{\mathrm{b}}$ & $6.16^{\mathrm{a}}$ & $4.97^{\mathrm{b}}$ & $5.58^{\mathrm{ab}}$ & $<0.0001$ & 0.1491 \\
\hline Aro1 & $4.16^{\mathrm{a}}$ & $3.74^{\mathrm{ab}}$ & $3.32^{\mathrm{abc}}$ & $3.13^{\mathrm{bc}}$ & $3.16^{\mathrm{bc}}$ & $3.15^{\mathrm{bc}}$ & $2.82^{\mathrm{c}}$ & 0.0001 & 0.1058 \\
\hline Aro2 & $2.19^{\mathrm{ab}}$ & $1.21^{\mathrm{c}}$ & $1.2^{\mathrm{c}}$ & $1.74^{\mathrm{bc}}$ & $1.35^{\mathrm{c}}$ & $2.54^{\mathrm{a}}$ & $2.17^{\mathrm{ab}}$ & $<00001$ & 0.1915 \\
\hline Aro3 & $0.43^{\mathrm{b}}$ & $1.93^{\mathrm{a}}$ & $1.56^{\mathrm{a}}$ & $1.95^{\mathrm{a}}$ & $1.99^{\mathrm{a}}$ & $0.61^{\mathrm{b}}$ & $0.67^{\mathrm{b}}$ & $<0.0001$ & 0.4337 \\
\hline Fla1 & $6.7^{\mathrm{a}}$ & $5.66^{\mathrm{b}}$ & $5.52^{\mathrm{bc}}$ & $4.98^{\mathrm{c}}$ & $7.09^{\mathrm{a}}$ & $3.38^{\mathrm{d}}$ & $2.54^{\mathrm{e}}$ & $<0.0001$ & 0.7669 \\
\hline Fla2 & $0.63^{\mathrm{b}}$ & $2.49^{\mathrm{a}}$ & $2.22^{\mathrm{a}}$ & $2.27^{\mathrm{a}}$ & $2.46^{\mathrm{a}}$ & $1.13^{\mathrm{b}}$ & $1.11^{\mathrm{b}}$ & $<0.0001$ & 0.3193 \\
\hline Fla3 & $1.68^{\mathrm{b}}$ & $1.37^{\mathrm{b}}$ & $1.62^{\mathrm{b}}$ & $1.73^{\mathrm{b}}$ & $1.41^{\mathrm{b}}$ & $1.82^{\mathrm{b}}$ & $2.62^{\mathrm{a}}$ & $<0.0001$ & 0.1225 \\
\hline Tex1 & $5.45^{\mathrm{a}}$ & $5.79^{\mathrm{a}}$ & $6.78^{\mathrm{a}}$ & $4.82^{\mathrm{a}}$ & $6.64^{\mathrm{a}}$ & $5.63^{\mathrm{a}}$ & $5.40^{\mathrm{a}}$ & 0.0860 & 0.0439 \\
\hline Tex2 & $2.68^{c}$ & $6.01^{\mathrm{ab}}$ & $6.3^{\mathrm{a}}$ & $6.37^{\mathrm{a}}$ & $6.48^{\mathrm{a}}$ & $5.26^{\mathrm{b}}$ & $3.32^{\mathrm{c}}$ & $<0.0001$ & 0.5928 \\
\hline Tex3 & $1.27^{\mathrm{d}}$ & $2.93^{\mathrm{a}}$ & $2.23^{\mathrm{bc}}$ & $2.76^{\mathrm{ab}}$ & $2.89^{\mathrm{ab}}$ & $1.92^{\mathrm{cd}}$ & $1.67^{\mathrm{cd}}$ & $<0.0001$ & 0.2857 \\
\hline Tex4 & $4.51^{\mathrm{b}}$ & $2.42^{\mathrm{d}}$ & $2.89^{\mathrm{cd}}$ & $6.53^{\mathrm{a}}$ & $3.62^{\mathrm{c}}$ & $5.83^{\mathrm{a}}$ & $4.59^{\mathrm{b}}$ & $<0.0001$ & 0.6343 \\
\hline Tex5 & $5.64^{\mathrm{a}}$ & $2.64^{\mathrm{c}}$ & $2.97^{\mathrm{bc}}$ & $2.38^{c}$ & $2.29^{c}$ & $3.73^{\mathrm{b}}$ & $5.18^{\mathrm{a}}$ & $<0.0001$ & 0.5180 \\
\hline Tex6 & $7.55^{\mathrm{a}}$ & $6.82^{\mathrm{b}}$ & $7.56^{\mathrm{a}}$ & $6.73^{\mathrm{b}}$ & $7.58^{\mathrm{a}}$ & $7.02^{\mathrm{b}}$ & $7.72^{\mathrm{a}}$ & $<0.0001$ & 0.3563 \\
\hline
\end{tabular}

*Means with a same superscript letter are not significantly different (p > 0.05). Samples [PDR: Standard; SG-1: gluten free (mix-1); SGD-1: gluten free (mix-1); SG+1: Gluten free $(\operatorname{mix}+1)$; SGD+1: Gluten free $(\operatorname{mix}+1)$; SGSF: Gluten free (mix w/o corn flour); SGFD: Gluten free (mix w/o corn flour)]; and Attributes [Color1 (Crumb yellow color); Color2 (Crust yellow color); App1 (Dry appearance); App2 (Porosity); Aro1 (Sweet aroma); Aro1 (Carrot aroma); Aro2 (Corn flour aroma); Fla1 (Sweetness); Fla2 (Corn flour flavor); Fla3 (Carrot flavor); Tex1 (Moisture); Tex2 (Fracturability); Tex3 (Sandiness); Tex4 (Adhesiviness); Tex5 (Smoothness); Tex6 (Elasticity)].

In regards to the residuals by configuration (Figure 2) the Expert 1 had the highest value, which means that he gave rates that do not match the consensus.

Figure 3 provides scaling factors of the GPA transformations. A lower factor than 1 suggests the corresponding expert was using a wider scale than the others. A higher factor than 1 implies the corresponding expert was not using the rating scale as widely as the other experts. So, the expert 5 probably used the sensory scale in a wrong way when compared to the others. 


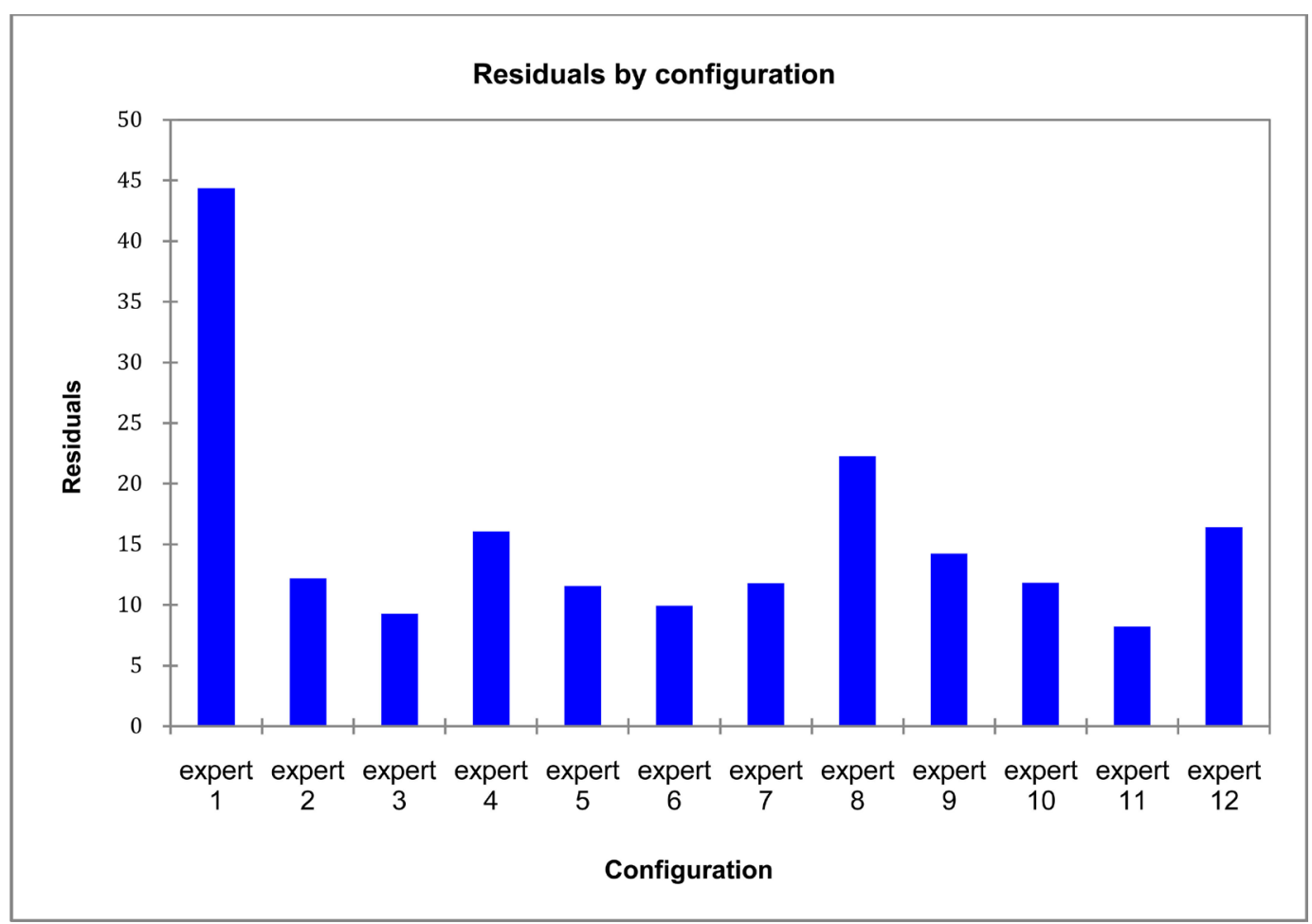

Figure 2. Residuals by configuration (GPA analysis).

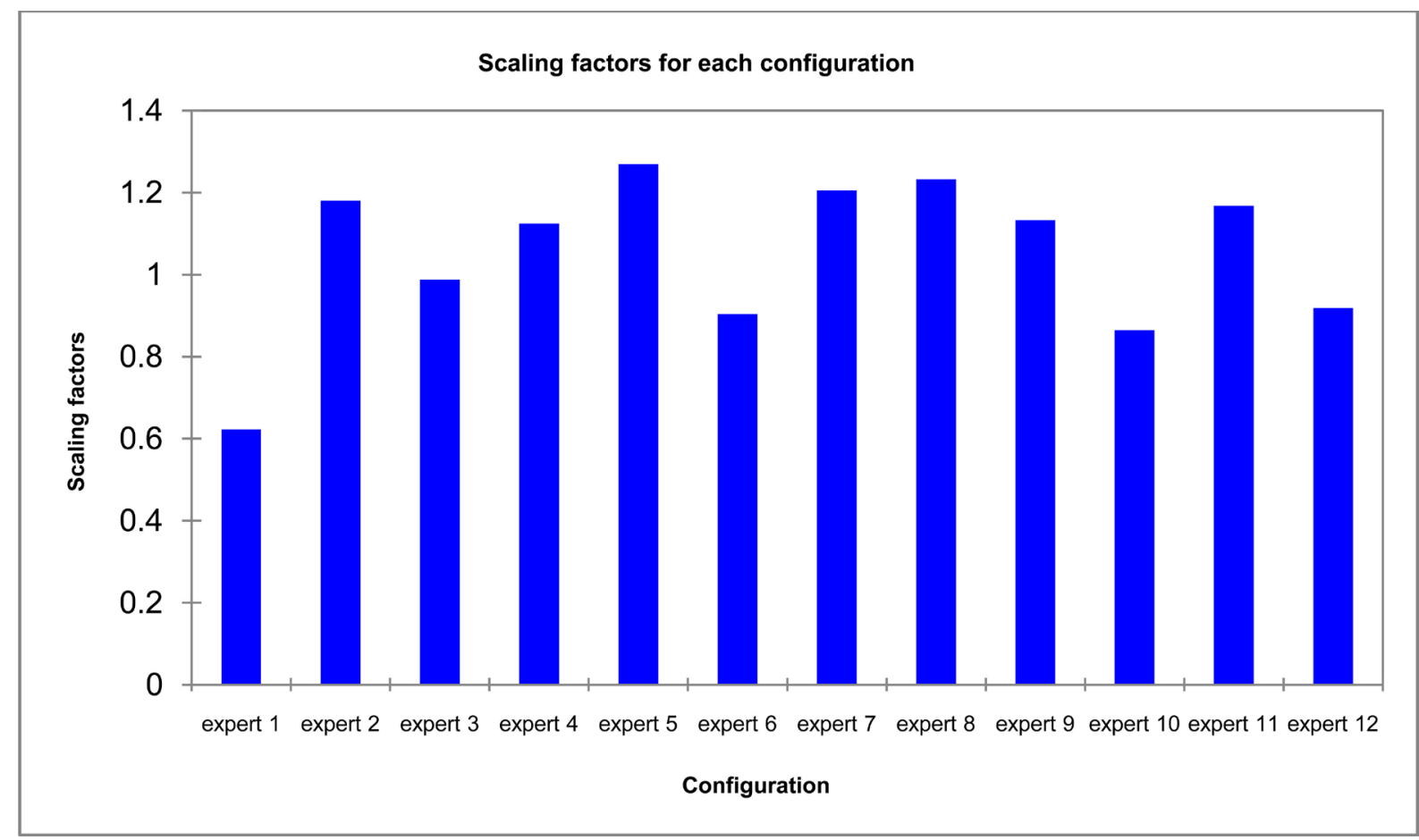

Figure 3. Scaling factors for each configuration (GPA analysis).

The eigenvalues showed how much of the variability corresponds to each axis (Table 7). It was possible to note that $79 \%$ of the variability was represented on the third axes. When the variability was split between the experts, the results were almost similar for all experts. 
In regards to Figure 4 all points were close to the first axis because $45 \%$ of the variability was concentrated on the first axis.

The samples PDR, SG-1, SGD-1 and SG+1 were sharply separated on the map, while the other products SGD+1, SGFD and SGSF weren't so conjoint. These results means that the samples PDR, SG-1, SGD-1 and SG +1 were better differentiated by experts and there was a consensus about these products.

According to the eigenvalues, $44.71 \%$ of variability was explained by dimension 1 , and $18.89 \%$ by dimension 2. So, the aroma attributes closer to dimension 1 were mainly determinants on the variation of seven carrot cake samples.

So, the expert 1 was rejected from the group and the QDA sensory data was used to correlation.

The two PCA components of Figure 5 can explain $68.65 \%$ of variability between samples. Attributes of moisture, yellow color crumb, yellow color crust, cornmeal aroma, cornmeal flavor, sandness, fracturability and sweetness (positively) and elasticity, carrot aroma, carrot flavor, dry appearance (negatively) contributed to the variability associated with the principal component I. Porosity, Fruity and Aroma Smoothness (positively) and Adhesiviness (negatively) were the main contributors to the variability associated with the main component II.

\subsection{Instrumental Analysis and Correlation}

The instrumental means obtained were presented in Table 8 .

According to Figure 6, the PLS regression associated instrumental parameters with overall liking results. The samples in this map were distributed and positioned to its pairs (gluten-free sucrose and its diet version), giving the understanding that the pairs have similar texture characteristics. It is also seen regarding overall liking, since the samples most preferred by the consumers were the samples PDR, SG-1 and SGD-1, which present cohesiveness, smoothness and elasticity; the texture characteristics closest to the overall liking.

Table 7. Eigenvalues - the axis variability.

\begin{tabular}{cccc}
\hline & F1 & F2 & F3 \\
\hline Eigenvalue & 9667 & 4085 & 3350 \\
Variability (\%) & 44,708 & 18,894 & 15,492 \\
Cumulative (\%) & 44,708 & 63,603 & 79,095 \\
\hline
\end{tabular}

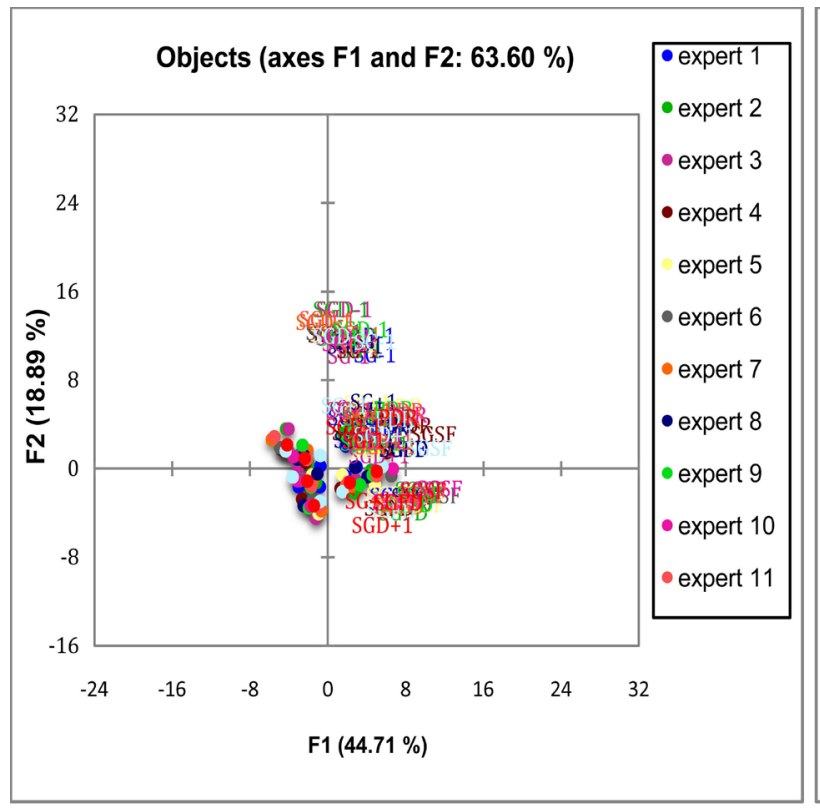

(a)

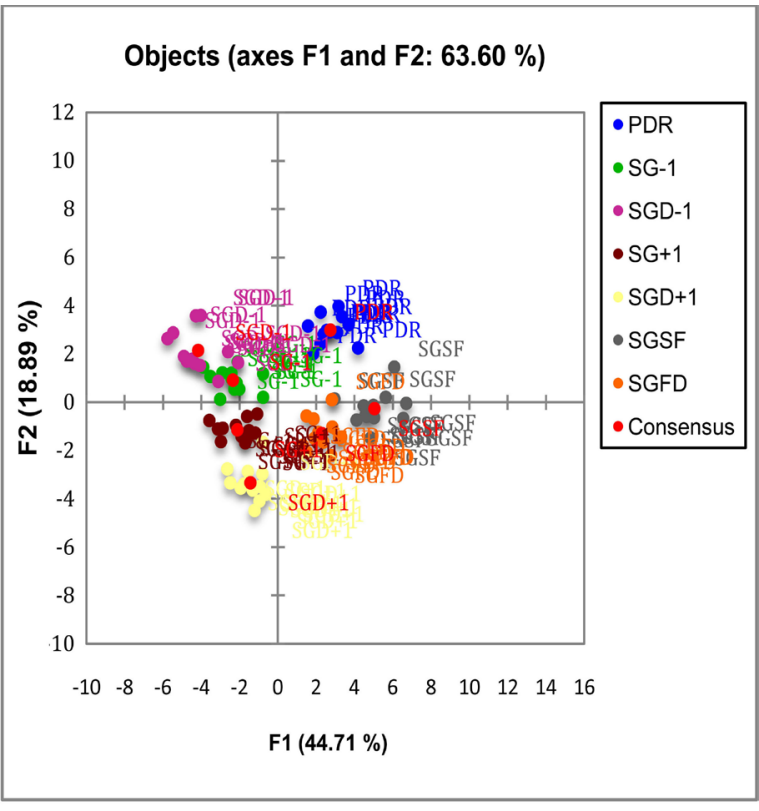

(b)

Figure 4. GPA analysis (a) by configuration and (b) by objects. 


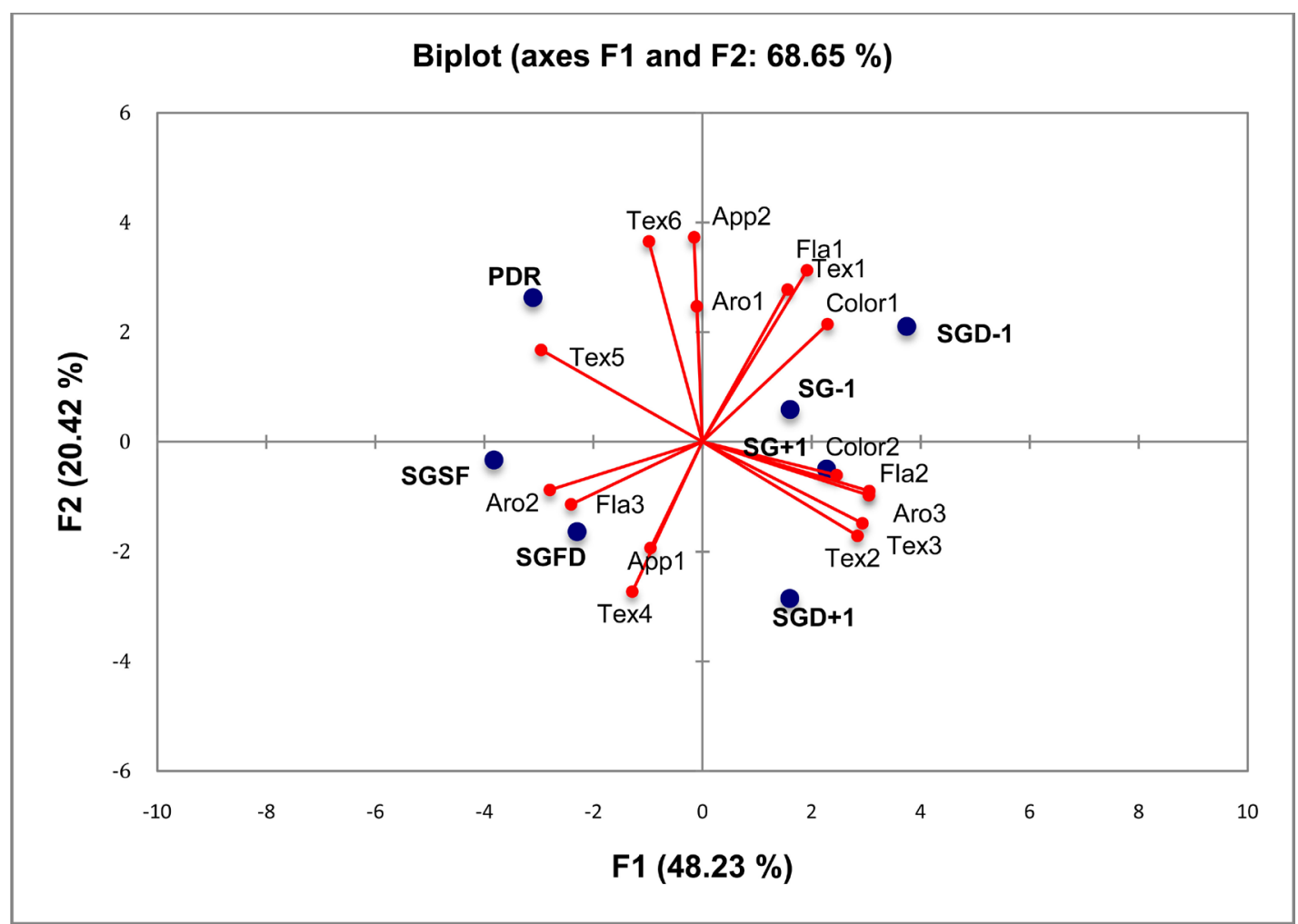

Figure 5. Principal Component Analysis QDA ( $=11)$ and hedonictest $(\mathrm{n}=120)$; Samples [PDR: Standard; SG-1: gluten free (mix-1); SGD-1: gluten free (mix-1); SG+1: Gluten free (mix+1); SGD+1: Gluten free (mix+1); SGSF: Gluten free (mix w/o cornmeal); SGFD: Gluten free (mix w/o cornmeal)] and attributes [Color1 (Crumb yellow color); Color2 (Crust yellow color); App1 (Dry appearance); App2 (Porosity); Aro1 (Sweet aroma); Aro1 (Carrot aroma); Aro2 (Cornmeal aroma); Fla1 (Sweetness); Fla2 (Cornmeal flavor); Fla3 (Carrot flavor); Tex1 (Moisture); Tex2 (Fracturability); Tex3 (Sandiness); Tex4 (Adhesiviness); Tex5 (Smoothness); Tex6 (Elasticity)].

Table 8. Results from texture and water activity parameters of carrot cake.

\begin{tabular}{cccccccccc}
\hline Attributes & PDR & SG+1 & SGD +1 & SG-1 & SGD-1 & SGFD & SGSF & Pr $>$ F & $R^{2}$ \\
\hline Hardness & $5093.0^{\mathrm{a}}$ & $4774.7^{\mathrm{a}}$ & $1417.7^{\mathrm{c}}$ & $4368.0^{\mathrm{ab}}$ & $2582.7^{\mathrm{abc}}$ & $1348.3^{\mathrm{c}}$ & $1989.0^{\mathrm{bc}}$ & 0.0006 & 0.7817 \\
Fracturability & $5093.0^{\mathrm{a}}$ & $4774.7^{\mathrm{a}}$ & $1417.7^{\mathrm{c}}$ & $4368.0^{\mathrm{ab}}$ & $2582.7^{\mathrm{abc}}$ & $1348.3^{\mathrm{c}}$ & $1989.0^{\mathrm{bc}}$ & 0.0006 & 0.7817 \\
Adhesiveness & $6.32^{\mathrm{a}}$ & $2.38^{\mathrm{a}}$ & $81.41^{\mathrm{ab}}$ & $0.98^{\mathrm{a}}$ & $25.54^{\mathrm{ab}}$ & $168.20^{\mathrm{b}}$ & $39.14^{\mathrm{ab}}$ & 0.0219 & 0.6089 \\
Smoothness & $0.75^{\mathrm{ab}}$ & $0.78^{\mathrm{a}}$ & $0.72^{\mathrm{ab}}$ & $0.75^{\mathrm{ab}}$ & $0.77^{\mathrm{a}}$ & $0.63^{\mathrm{b}}$ & $0.79^{\mathrm{a}}$ & 0.0105 & 0.6537 \\
Cohesiveness & $0.38^{\mathrm{a}}$ & $0.34^{\mathrm{a}}$ & $0.30^{\mathrm{a}}$ & $0.34^{\mathrm{a}}$ & $0.33^{\mathrm{a}}$ & $0.28^{\mathrm{a}}$ & $0.37^{\mathrm{a}}$ & 0.0409 & 0.5650 \\
Gumminess & $1939.0^{\mathrm{a}}$ & $1601.7^{\mathrm{ab}}$ & $441.7^{\mathrm{c}}$ & $1508.7^{\mathrm{ab}}$ & $864.3^{\mathrm{bc}}$ & $391.0^{\mathrm{c}}$ & $750.3^{\mathrm{bc}}$ & 0.0004 & 0.7948 \\
Chewiness & $1451.0^{\mathrm{a}}$ & $1254.7^{\mathrm{ab}}$ & $325.3^{\mathrm{c}}$ & $1124.0^{\mathrm{ab}}$ & $671.7^{\mathrm{bc}}$ & $252.7^{\mathrm{c}}$ & $600.7^{\mathrm{bc}}$ & 0.0002 & 0.8147 \\
Elasticity & $0.17^{\mathrm{a}}$ & $0.19^{\mathrm{a}}$ & $0.14^{\mathrm{a}}$ & $0.19^{\mathrm{a}}$ & $0.16^{\mathrm{a}}$ & $0.14^{\mathrm{a}}$ & $0.19^{\mathrm{a}}$ & 0.0529 & 0.5452 \\
Aw & $0.89^{\mathrm{b}}$ & $0.90^{\mathrm{ab}}$ & $0.92^{\mathrm{ab}}$ & $0.91^{\mathrm{ab}}$ & $0.93^{\mathrm{a}}$ & $0.92^{\mathrm{ab}}$ & $0.91^{\mathrm{ab}}$ & 0.5940 & 0.0273 \\
\hline
\end{tabular}

${ }^{*}$ Means with a same superscript letter are not significantly different (p > 0.05). Samples [PDR: Standard; SG-1: gluten free (mix-1); SGD-1: gluten free (mix-1); SG+1: Gluten free (mix+1); SGD+1: Gluten free (mix+1); SGSF: Gluten free (mix w/o corn flour); SGFD: Gluten free (mix w/o corn flour)]; and Attributes [Aw (water activity)].

Despite PLS results, Ylimaki et al. [25] affirm that hardness and gumminess were the most important parameters of gluten-free crumb cake quality.

Some studies have been considered sucralose as the sweetener that best substitutes sucrose [26]-[28]. Morais et al. [29] study reported that the sensory profile of dairy desserts with sucralose was similar than that one with sucrose; differed statistically ( $\mathrm{p} \leq 0.05$ ) only in relation to the attribute of brown color.

Preichardt et al. [30] got firmer and less elastic cakes using rice and corn mix flours, with middle fracturabili- 
ty. According to Tedrus et al. [31], wheat flour is the only one able to produce a viscoelastic mass with better gas holding during brew and first steps of baking, getting a softer food.

According to a study that had used wheat flour replacements in cookies, the results showed that instrumental attributes did not alter between traditional and quinoa flour samples. But, hardness increased when quinoa flour was used in high concentrations [32].

The substitution of sucrose by sucralose was shown to be successful, except for the sample SGD+1, which contains a large quantity of corn flour. The properties of cohesiveness and elasticity were the two texture parameters analysed as better accepted, while the other parameters weren't so considered by the consumers.

Similar results were successfully obtained in a recent study with diet milk chocolates sweetened with sucralose [33], using five different bulking agents (polydextrose, inulin, fructo-oligosaccharides, lactitol and maltitol).

In milk chocolates, sucralose was the best substitute of sucrose for diet purposes and for calories reduction [34]. As well the sucralose was evaluated by other sensory methods, as multiple time-intensity [35].

According to Lopez [17], bread quality is associated with gas hold by brew.

Rocha et al. [24] found that high corn flour content into corn cakes associated with less wheat flour concentration produced a soft mass and more fracturability product.

The Contour plot (Figure 7) reported that the vector is the best model for clusters 1 and 3 to 6 . The circular is the significant model for cluster 2 and inside of it there is an ideal point $(-0.772 ; 0.704)$, corresponding to the highest preference by judges.

As shown in the Contour plot, samples SGFD and SGSF were located in a region that included acceptance values above the overall value for $80 \%$ to $100 \%$ of consumers. The traditional sample is located in a region with $60 \%$ to $80 \%$ of preference consumers.

Gaze et al. [36] also used an external preference mapping associated with Quantitative Descriptive Analysis attributes to determine consumer acceptability of caramelized milk.

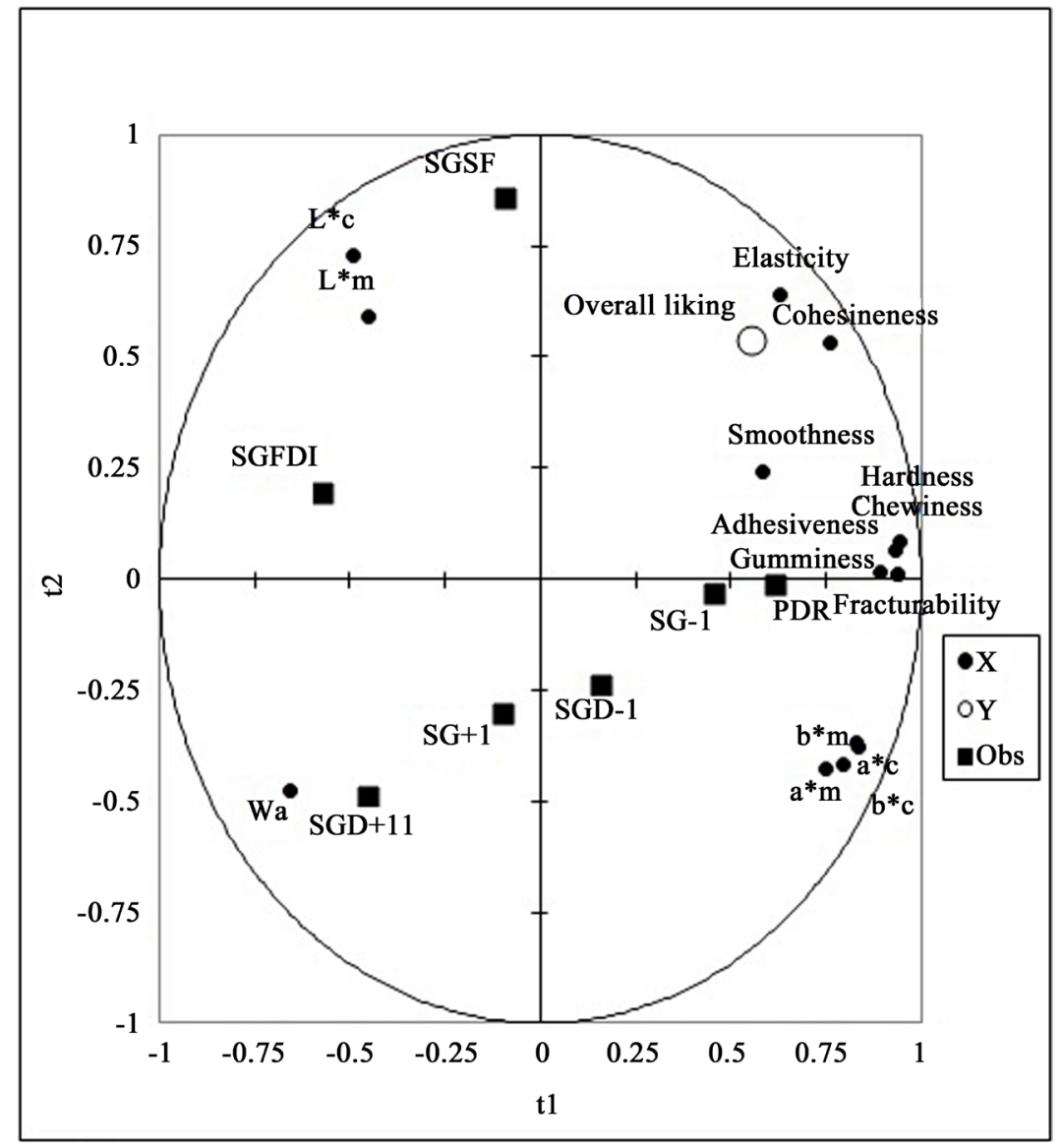

Figure 6. PLS regression (instrumental and overall liking parameters). 


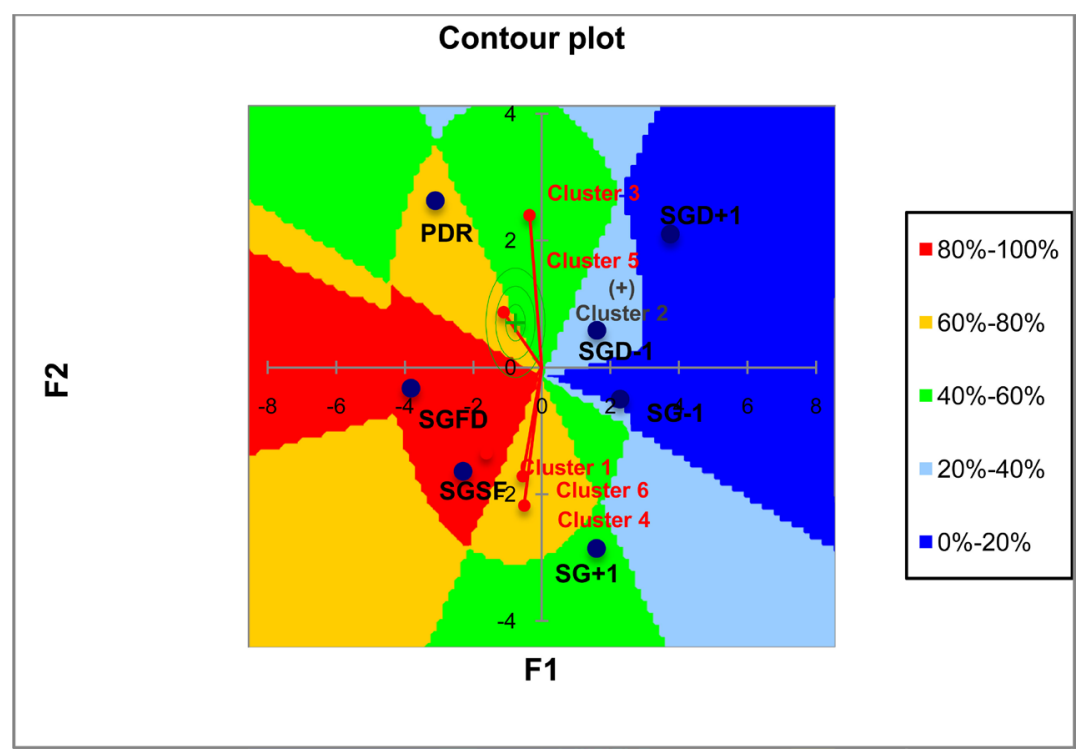

Figure 7. Preference mapping illustrating 6 clusters: 1, 3, 4, 5 and 6 [vector] and 2 [circular (+); where the plus indicates a maximum point in terms of preference]; Samples [PDR: Standard; SG-1: gluten free (mix-1); SGD-1: gluten free (mix-1); SG+1: Gluten free $(m i x+1)$; SGD+1: Gluten free $(m i x+1)$; SGSF: Gluten free (mix w/o cornmeal); SGFD: Gluten free (mix w/o cornmeal)] and the 5 regions of the global average value of acceptance.

\section{Conclusions}

The correlation takes interest for the evaluation of the sensory properties for quality control and applications in product development. External map provides a correlation with consumer hedonic scores regressed in a perceptual map, which should be understood as the acceptance drivers of a gluten-free baked food.

Wheat flour replacement in carrot cake showed some sensory property changes; however these characteristics could be improved with some quality control settings. Thus, it's possible to conclude that wheat flour and sucrose replacement is applicable as long as it maintains consumers' expectations.

\section{References}

[1] Sdepanian, V.L., Morais, M.B. and Fagundes-Neto, U. (2001) Doença celíaca: Avaliação da obediência à dieta isenta de glúten e do conhecimento da doença pelos pacientes cadastrados na Associação dos Celíacos do Brasil (ACELBRA). Archives of Gastroenterology, 38, 4. http://dx.doi.org/10.1590/s0004-28032001000400005

[2] Pratesi, R. and Grandolfi, L. (2005) Doença Celíaca: A afecção com múltiplas faces. Journal of Pediatrics, 81, 357358. http://dx.doi.org/10.1590/s0021-75572005000600002

[3] Araujo, H.M.C. (2008) Impacto da Doença Celíaca na saúde, nas praticas alimentares e na qualidade de vida de celíacos. Dissertação de Mestrado. Programa de pós-graduação em nutrição humana. Universidade de Brasilia. Brasilia, 98 p.

[4] Araujo, H.M.C., Araujo, W.M.C., Botelho, R.B.A. and Zandonadi, R.P. (2010) Doença celíaca, hábitos e práticas alimentares e qualidade de vida. Brazilian Nutrition Journal, 23, 467-474. http://dx.doi.org/10.1590/s1415-52732010000300014

[5] FAO—Food Agriculture Organization (2001) Food Balance Sheet. Boletim da Organização das Nações Unidas para Agricultura e Alimentação.

[6] Beyer, P.L. (2002) Terapia clinica nutricional para distúrbios do trato gastrointestinal baixo. In: Krause, M.V., Ed., Alimentos, Nutrição e Dietoterapia, 10th Edition, Rocca, Sao Paulo, 643-670.

[7] Lopez, A.C.B., Pereira, A.J. and Junqueira, R.G. (2004) Flour Mixture of Rice Flour, Corn and Cassava Starch in the Production of Gluten-Free White Bread. Brazilian Archive of Biology and Technology, 47, 63-70. http://dx.doi.org/10.1590/S1516-89132004000100009

[8] Instituto Brasileiro de Geografia e Estatística (2010) Pesquisa de Orçamentos Familiares, 2008-2009. Antropometria e estado nutricional de crianças, adolescentes e adultos no Brasil.

[9] Cardello, H.M.A.B. and Faria, J.B. (2000) Análise da aceitação de aguardentes de cana por testes afetivos e mapa de 
preferência interno. Brazilian Food Science and Technology, 20, 32-36. http://dx.doi.org/10.1590/s0101-20612000000100007

[10] Gower, J.C. (1975) Generalized Procrustes Analysis. Psychometrika, 40, 33-50. http://dx.doi.org/10.1007/BF02291478

[11] Murray, J.M., Delahunty, C.M. and Baxter, I.A. (2001) Descriptive Sensory Analysis: Past, Present and Future. Food Research International, 34, 461-471. http://dx.doi.org/10.1016/S0963-9969(01)00070-9

[12] MacFie, H. (2007) Preference Mapping and Food Product Development. In: MacFie, H., Ed., Consumer-Led Product Development. Woodhead Publishing Limited, Cambridge. http://dx.doi.org/10.1533/9781845693381.3.551

[13] Van Kleef, E., Van Trijp, H.C.M. and Luning, P. (2006) Internal versus External Preference Analysis: An Exploratory Study on End-User Evaluation. Food Quality and Preference, 17, 387-399. http://dx.doi.org/10.1016/j.foodqual.2005.05.001

[14] MacFie, H.J., Bratchell, N., Greenhoff, K. and Vallis, L.V. (1989) Designs to Balance the Effect of Order of Presentation and First-Order Carry-Over Effect in Halls Tests. Journal of Sensory Studies, 4, 129-148. http://dx.doi.org/10.1111/j.1745-459X.1989.tb00463.x

[15] Moskowitz, H.R. (1983) Product Testing and Sensory Evaluation of Foods. Food and Nutrition Press, 605 p.

[16] Damásio, M.H. and Costell, E. (1991) Análisis sensorial descriptivo: Generación de descriptores y selección de catadores. Revista de Agroquímica y Tecnología de Alimentos, 31, 165-178.

[17] Smith, S.M. (1990) PC-MDS-Multidimensional Statistic Package, Version 5.1. Institute of Business MGT, Brigham Young University, Provo, $309 \mathrm{p}$.

[18] XLSTAT (2006) XLSTAT 2006. Help, Addinsoft Inc., Paris.

[19] Arnold, G.M. and Williams, A.A. (1986) The Use of Generalized Procrustes Technique in Sensory Analysis. In: Piggott, J.R., Ed., Statistical Procedures in Food Research, Elsevier Applied Science, London, 233-255.

[20] Oreskovich, D.C., Klein, B.P. and Sutherland, J.W. (1991) Procrustes Analysis and Its Application to Free-Choice and Other Sensory Profiling. In: Lawless, H.T. and Klein, B., Eds., Sensory Science Theory and Applications in Food, Marcel Dekker, New York, 353-393.

[21] Tenenhaus, M., Vinzi, V.E., Chatelin, Y. and Lauro, C. (2005) PLS Path Modeling. Computational Statistics and Data Analysis, 48, 159-205. http://dx.doi.org/10.1016/j.csda.2004.03.005

[22] Sae-Eaw, A., Chompreeda, P., Prinyawiwatkul, W., Haruthaithanasan, V., Suwonsichon, T., Saidu, J.E. and Xu, Z. (2007) Acceptance and Purchase Intent of US Consumers for Nonwheat Rice Butter Cakes. Journal of Food Science, 72, 92-97. http://dx.doi.org/10.1111/j.1750-3841.2006.00256.x

[23] Battochio, J.R., Cardoso, J.M., Kikuchi, M., Macchione, M., Modolo, J.S., Paixão, A.L., Pinchelli, A.M., Silva, A.R., Sousa, V.C., Wada, J.K.A., Wada, J.K.A. and Bolini, H.M. (2006) Perfil Sensorial de pão de forma integral. Brazilian Food Science and Technology, 26, 428-433.

[24] Rocha, F.L., Minim, V.P.R., Della Lucia, F., Minim, L.A. and Coimbra, J.S.D.R. (2003) Effects of QPM Addition on the Sensory Characteristics of Cake Maize. Journal of Food Science and Technology, 23, 129-134.

[25] Ylimaki, G., Hawrysh, Z.J., Hardin, R.T. and Thomson, A.B.R. (1991) Response Surface Methodology in the Development of Rice Flour Yeast Breads: Sensory Evaluation. Journal of Food Science, 56, 751-755. http://dx.doi.org/10.1111/j.1365-2621.1991.tb05374.x

[26] Brito, C.A.K. and Bolini, H.M.A. (2010) Sensory Profile of Sweeteners in Guava Nectar. Alimentos e Nutrição (UNESP. Marília), 20, 561-572.

[27] Cadena, R.S., Cruz, A.G., Netto, R.R., Castro, W.F., Faria, J.A.F. and Bolini, H.M.A. (2013) Sensory Profile and Physicochemical Characteristics of Mango Nectar Sweetened with High Intensity Sweeteners throughout Storage Time. Food Research International, 54, 1670-1679. http://dx.doi.org/10.1016/j.foodres.2013.10.012

[28] De Marchi, R., McDaniel, M. and Bolini, H.M.A. (2009) Formulating a New Passion Fruit Juice Beverage with Different Sweetener Systems. Journal of Sensory Studies, 24, 698-711. http://dx.doi.org/10.1111/j.1745-459X.2009.00234.x

[29] Morais, E.C., Lima, G.C., Morais, A.R. and Bolini, H.M.A. (2015) Prebiotic and Diet/Light Chocolate Dairy Dessert: Chemical Composition, Sensory Profiling and Relationship with Consumer Expectation. LWT_Food Science and Technology, 62, 424-430.

[30] Preichardt, L.D., Vendruscolo, C.T., Gularte, M.A. and Moreira, A.D.S. (2009) Efeito da goma xantana nas características sensoriais de bolos sem glúten. Revista Brasileira de Tecnologia Agroindustrial, 3, 70-76. http://dx.doi.org/10.3895/S1981-36862009000100007

[31] Tedrus, G., Cássia, R.S., Speranza, S.M., Chang, Y.K. and Bustos, F.M. (2001) Estudo da adição de vital glúten à farinha de arroz, farinha de aveia e amido de trigo na qualidade de pães. Journal of Food Science and Technology, 21, $20-25$. 
[32] Bick, M.A., Fogaça, A.O. and Storck, C.R. (2014) Biscoitos com diferentes concentrações de farinha de quinoa em substituição parcial à farinha de trigo. Brazilian Journal of Food Tecnhology, 17, 121-129. http://dx.doi.org/10.1590/bjft.2014.015

[33] Gomes, C.R., Vissotto, F.Z., Fadini, A.L., Faria, E.V. and Luiz, A.M. (2007) Influence of Different Bulk Agents in the Rheological and Sensory Characteristics of Diet and Light Chocolate. Brazilian Food Science and Technology, 27, 614-623.

[34] Palazzo, A.B., Carvalho, M.A.R., Efraim, P. and Bolini, H.M.A. (2011) The Determination of Isosweetness Concentrations of Sucralose, Rebaudioside and Neotame as Sucrose Substitutes in New Diet/Light Chocolate Formulations Using the Time Intensity Analysis. Journal of Sensory Studies, 26, 291-297. http://dx.doi.org/10.1111/j.1745-459X.2011.00344.x

[35] Palazzo, A.B. and Bolini, H.M.A. (2014) Multiple Time-Intensity Analysis: Sweetness, Bitterness, Chocolate Flavor and Melting Rate of Chocolate with Sucralose, Rebaudioside and Neotame. Journal of Sensory Studies, 29, 21-32. http://dx.doi.org/10.1111/joss.12078

[36] Gaze, L.V., Oliveira, B.R., Ferrao, L.L., Granato, D., Cavalcanti, R.N., Júnior, C.C. and Freitas, M.Q. (2015) Preference Mapping of Dulce de Leche Commercialized in Brazilian Markets. Journal of Dairy Science, 98, 1443-1454. http://dx.doi.org/10.3168/jds.2014-8470

\section{Submit or recommend next manuscript to SCIRP and we will provide best service for you:}

Accepting pre-submission inquiries through Email, Facebook, Linkedin, Twitter, etc A wide selection of journals (inclusive of 9 subjects, more than 200 journals)

Providing a 24-hour high-quality service

User-friendly online submission system

Fair and swift peer-review system

Efficient typesetting and proofreading procedure

Display of the result of downloads and visits, as well as the number of cited articles

Maximum dissemination of your research work

Submit your manuscript at: http://papersubmission.scirp.org/ 